○第 11 回日本ゴム協会賞受賞者報告○

\section{新規な樹脂改質用水添ポリマー の開発}

\author{
JSR 株式会社 竹村泰彦・寺本俊夫 · \\ 神品順二 \\ テクノポリマー株式会社 今井高照 \\ 株式会社エラストミックス 竹内幹雄
}

この度は，名誉ある日本ゴム協会賞受賞の 栄に浴し，光栄に存じます。これも，本開発 にあたり種々御教示いただきましたユーザー 各位始め多くの方々のお莶と，本関係者一同 厚く御礼申し上げます。以下，本開発の概要 について御説明致します。

\section{1 . 開発の背景}

加硫ゴムを大幅に上回る伸びを示してきた 熱可塑性エラストマー(TPE) は, 1980 年代 後半にはその率は小さくなってきていました が，依然樹脂改質用途を中心に伸長を続けて いました。このような状況下，本関係者等は 新規なエラストマーを検討にするにあたり， 弊社が永年培ってきた溶液重合 SBRの重 合・分子設計技術(リビングアニオン重合技 術) と，これも永きにわたり折に触れて検討 していた水素添加 (水添)技術を駆使，あるい は更にブラッシュアップして，樹脂改質用に ターゲットを定めた高性能・高機能水添ポリ マー開発を企画，実行することにしました。

\section{2. 技術開発の内容}

まず，水添触媒は品質・生産性を考慮して， 広い温度範囲で高活性が維持できる触媒系を 見い出しました。一方，本開発の基本となる ポリマーの分子設計にあたっては，既成の技 術に捕われることなく，樹脂改質用のポリマ 一として好適な分子設計を広く探索しまし た。その際，樹脂としては当時から伸長が予 測されていたポリプロピレン (PP)，ポリ工 チレン $(\mathrm{PE})$ などのポリオレフィンを中心に 据えて検討することにしました，検討の結 果, 従来顧みられなかった高ブチレンタイプ のエチレン/ブチレン $(\mathrm{EB})$ や低ブチレンタイ プの $\mathrm{EB}$ (これは結晶化するため, Crystalline を略し C と表示)を含む水添ポリマーが，PP

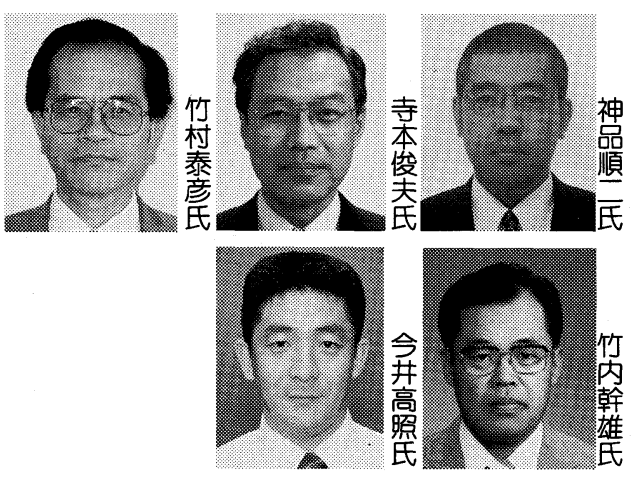

や PE 改質に特異な機能を発揮することを見 い出しました，次のような例を挙げることが できます。

1) 高ブチレンタイプの水添 SBR (HSBR) は, PP 中に $10 \mathrm{~nm}$ オーダーに微分散し,

PP をオイルフリーで軟質し，かつ透明化 する.

2 ) ステレオブロック BR を水添した CEBC は，PEを軟質化するとともに強度も向上 させる，あるいは $\mathrm{PP} / \mathrm{PE} の$ 相溶化剂とし て働く.

これらの知見から，種々の特性を有する HSBR，SEBC， CEBC を設計することが可 能となりました。

\section{3. 商品化の経緯}

1989 年末の高ブチレン HSBR を中心とし たプロトタイプによるプレサウンドを経て, 1992 年に正式上市しました。以後ユーザー各 位の適切な御評価・助言をいただきながら $\mathrm{SEBC}, \mathrm{CEBC}$ もラインアップし現在に至っ ています。

用途は PP 改質を中心に PE，PS 改質用が 多く，とりわけPP とのブレンドでポスト PVC 材料として, 自動車部品, 工業用品, 日用品，医療用途，およびフィルム用途など 広い領域にわたっています。

最近，環境問題は更に大きな高まりを見せ ており，これらの新規水添ポリマーはますま すユーザー各位から興味をもって迎えられて います。それらの御要望にお応えすべく，昨 秋生産プラントの能力増強も行いました。

今後もユーザー各位のお役に立つべく, 更 に研究開発, 安定生産に精進していく所存で す。これらの開発品に対し，倍旧の御愛顧を お願いする次第です。 